Open Access

\title{
The disporia of borders: Hindu-Sikh transnationals in the diaspora
}

\author{
Purushottama Bilimoria ${ }^{1,2}$ (D)
}

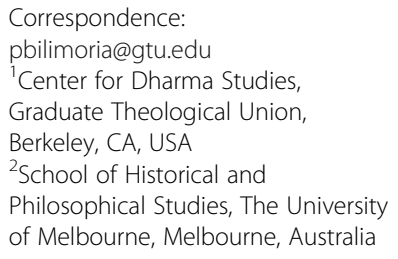

Correspondence: pbilimoria@gtu.edu ${ }^{1}$ Center for Dharma Studies, Graduate Theological Union, Berkeley, CA, USA

${ }^{2}$ School of Historical and Philosophical Studies, The University of Melbourne, Melbourne, Australia

\begin{abstract}
This paper offers a set of nuanced narratives and a theoretically-informed report on what is the driving force and motivation behind the movement of Hindus and Sikhs from one continent to another (apart from their earlier movement out of the subcontinent to distant shores). What leads them to leave one diasporic location for another location? In this sense they are also 'twice-migrants'. Here I investigate the extent and nature of the transnational movement of diasporic Hindus and Sikhs crossing borders into the U.S. and Australia - the new dharmic sites - and how they have tackled the question of the transmission of their respective dharmas within their own communities, particularly to the younger generation. Two case studies will be presented: one from Hindus and Sikhs in Australia; the other from California (temples and gurdwaras in Silicon Valley and Bay Area).
\end{abstract}

Keywords: Indian diaspora, Hindus, Sikhs, Australia, India, Transnationalism, Diaspoetics, Adaptation, Globalization, Hybridity, Deterritorialization, Appadurai, Bhabha, Mishra

\section{Part I}

In keeping with the theme of Experimental Dharmas this article maps the contours of dharma as it crosses borders and distant seas: what happens to dharma and the dharmic experience in the new 'experiments of life' a migrant community might choose to or be forced to undertake? One wishes to ask and develop a hermeneutic for how the dharma traditions are reconfigured, hybridized and developed to cope and deal with the changed context, circumstances and ambience. But it is the people and their movement that we shall be most concerned with in highlighting this thematic juncture - and disjuncture.

The world of post-modernity-at-large is sometimes described as a transnational village: multiple borders have emerged and are sequestered, or crossed, and double-crossed, with regularity. The borders range from territorial, national, ethnic, cultural, religious and caste differentiations, to a quasi-secular porous identity of no fixed address. It is to be noted that the syntagm of 'transnationalism' (sometimes 'transglobalism') takes one beyond the erstwhile trope of 'diaspora'. To be sure, 'diaspora' does involve crossing borders: of nation-states, leaving behind 'ancestral homeland' in search for new social, economic, educational networks (Vertovec 1995: 277); but it becomes staid once the immigrants have settled and founded their stable new home. They may push on and push through certain frontiers, epistemically and socially: e.g. upgrade jobs; become a CEO of a major corporation, such as Microsoft; fight for better education of their children; build temples against local tempers; contest for a Senate seat or run for Governor of a

(c) The Author(s). 2017 Open Access This article is distributed under the terms of the Creative Commons Attribution 4.0 International License (http://creativecommons.org/licenses/by/4.0/), which permits unrestricted use, distribution, and reproduction in any medium, provided you give appropriate credit to the original author(s) and the source, provide a link to the Creative Commons license, and indicate if changes were made. 
conservative state; or launch desi-operated TV-channel. But the limits exhaust themselves, where resources, opportunities, and energies (might just) dry up. Transnationalism connotes taking risks and, in a spirit of experimentalism, being prepared to make a move and contingently cross a national frontier (i.e., the secondary nation-state). This journey may fray into extended territorial, even epistemic and political, boundaries, which may take place outside of the adopted homeland, i.e., toward other supplemental 'phoren' horizons and frontal silken valleys of opportunities - or, intermittently, looking back to the ancestral homeland (pardesi ghar-wapsi) (with its the temptations of low-taxes, high return investment, NRI-OCI privileges, supplemented with the coveted Pravasi Bharatiya Award). To capture the latter problematization of 'diaspora' with the emergent phenomenon of 'transnationalism,' Sudesh Mishra coined a neologism, namely, 'diaspoetics' (2006: 17-18). What Mishra intends to suggest by this literary marker is that the collective diasporic experience involves three phases of moves as it were in a poetical composition of a particular sort. These comprise: 'dual territoriality', 'situational laterality', and 'archival specificity'. In the first phase, the diasporic subject has a sense of dislocated identity between the stable host country and the former homeland, which is marked by 'living without belonging in one, belonging without living in the other'. In the second, the boundaries are transcended, there is a more fluid identity formation, and the diasporic citizen is ambivalent about physically returning to the former land. In the third, the subject moves away from both the above and questions the history and identity written as it were on his/her trans-migrated body, sometimes even turning to wider moral and religious reconfigurations to form a specific identity distinct from the above two.

Nonetheless, the peculiar origins of the term 'diaspora' in the homeless re-identification with the Jewish people still raise two issues that urge against its widespread adoption in the study of transnational migration and settlement of Hindus and Sikhs, namely:

- Most of the Hindus and Sikhs in the so-called diaspora are in actual fact expatriates who, it is said, 'chose to leave' and continue to have more concrete than virtual ties with the 'home-land', which is also real and not just a messianically imagined territory or so only in memory.

- The process of re-location elsewhere and concomitant psycho-social anomie of dislocation, displacement and the variables within the immigrant experience of Hindus, even among long-settled second-onwards generations, compounded with linguistic, ethnic, cultural and regional diversity, is not at all adequately captured by the descriptor, 'diaspora', or less so in postcolonial theory as we understand it. We therefore prefer disporia: the aporia of dislocation, disruption, distance and the limits of hybridization as also of distanciation. Thus our analysis will draw on the latter nuance even though we will stay mostly with the terms 'diaspora' and 'expatriate' interchangeably.

My argument is that the transnationalism of the sort I am adverting to here is a byproduct of globalization where everything moves, transits borderzones, with the swiftness of UPS packages: money, market, information, produce, labor, technology, skills, corporations as persons, trade, pollution, and even religion and hybridized cultures as multiplex modernities are included in this package, which upon arrival in the newer territorial frontier may well become capital for exchange and negotiations and identity linchpins. And 
there is a certain anomie that is experienced by the itinerant as the gaze turns toward the promising but unknown horizon: promising in terms of what it might take away from one's personal, social and cultural identity. Robin Cohen has summarized the contours of the diasporic angst rather succinctly.

a) A collective myth and memory about the homeland, including its location, history and achievements;

b) An idealization of the putative ancestral home, and a collective commitment to maintenance, restoration, safety and prosperity, even to its creation.

c) The development of a return movement which gains collective approbation.

d) A strong ethnic group consciousness sustained over a long time and based on a sense of distinctiveness, common history, and the belief of a common fate (Cohen 1997: 26).

Packaged with that heritage, legacy and diasporic imaginary behind it, an established diasporic group may look to or leave the adopted shores for another location for any number of reasons, and conjoin with members of their own community or faith in these new regions and spaces (territorial and perhaps even imaginary and virtual: Consider the Javanese Majapahits bringing their adopted Hinduism to Bali), so that the work of transmission may continue without undue interruption. Motivations for crossing the diasporic border may change from one epoch or generation to the next. In more recent times, escaping poverty or oppression, war-torn or ecologically ravaged homeground; seeking better employment or advancement opportunities and livelihood and education for offspring; transfers or re-location in one's professional position, vocation, or a call for further training could be other reasons; indeed, seeking marriageable partners could be yet another motivating factor (called the matrimonial imperative).

A newer and different process of transmission attuned to the altered environment may ensue.

Current theorizing on shifting borders has not dealt too deeply with religion (e.g., Mignolo 2009; Appadurai 2006), much less with South Asian religious communities (with mild exception of Hinnells, John 1998), but almost no studies exist on diasporic double-crossing in respect of the latter group (dvidesias, I call them now). This borderdouble-crossing transnational phenomenon is not well understood, thus I urge that we re-think territoriality and spiritual belonging in the post-secular moment to arrive at a deeper understanding of self and mobility.

There has been a steady increase in transnational movement of Hindus and Sikhs between Australia/Oceania, Britain, Singapore, on the one side, and North America, as the final destination, on the other side. Curiously, there was already some sign of this back in colonial times, with indentured laborers being exported to the colonies - what I call 'outsourced Indians'. They were taken to all corners of the expanding Empire, where they have remained, from which locations they have ventured to other frontiers, even more distant and unknown. Laborers also left on their own accord for free countries, outside the Empire. So, for example, in the opening years of the 1900s, Sikhs from Punjab arrived on the Pacific Coast of North America to escape persecution and the British Rāj (rule). After arriving in British Columbia, some drifted south and settled around Yuba City and Marysville in California, where they found work on the railroads and in the lumber mills. 
Others headed for the farm-fields of Sacramento Valley (they were called 'rag heads' or 'turbaned tide', or 'Hindoos'). They did well, having come from rural-agro backgrounds, and took over jobs from other (East) Asians; the money was good. Socially they were ostracized, and could not bring their women, so most married locally, especially with Mexicans who worked alongside them. But the conditions were not optimal and they faced opposition from both their Japanese rivals and white townsfolks; they soon learned to organize themselves, and came in contact with Sikh-Punjabi students, especially at UC Berkeley and Stanford, who were already supporting Bay Area Sikh workers to organize unions and mount protests for better, non-discriminatory working conditions. They had come under the influence of Tāraknāth Dās, an Oxford-trained student émigré, and impacted also by Har Dayāl, a revolutionary philosopher. The students and workers formed into a nationalist collective and began preparing to fight British rule in India, with military intervention, or mutiny, if needed. Indeed, so large and successful was this collective, called the Ghadar movement, in empowering nationalist-patriotic zeal at the onset of WWI that they teamed up with similar rebel groups in other countries opposed to the British Empire (such as Germany and Japan), and reached India where they inspired groups and even soldiers to revolt against the British. A ship with the largest contingent, some 100 Californian-trained Ghadar sepoys (mostly students from UC-Berkeley), tipped off by the British intelligence and the FBI (initially set up to monitor local protests and riots, especially of the 'colored' troops), was ambushed by the US Navy and the rebels were trucked off from Berkeley rolls and charged under some pretext of smuggling arms out of the country. Their survivors and kin subsequently went on to buy their own way into the Californian farming industry, and later built gurdwaras, schools, and community centers in rural California; if they are not wearing turbans, one would take them to be Mexicans (some indeed are hybrid Latino/a-Sikhs), and they are permitted to sit on chairs with shoes in the temple.

Of course, within North and Central America [notably via Mexico], there has been a continued search for lucrative gateways along the borders, mostly by disaffected Sikh and Sri Lankan Tamil Hindu refugees, seeking asylum or undocumented entry into or out of Canada, and thence to the United States.

However - and this is the central thesis of the paper - the movement is not ipso facto in one direction; for, with the onset of an economic decline in American industrial, I.T., soft-power base and Nano entrepreneurship, there has been some movement in the other direction as well, particularly among the so-called returning professionals. And still more arrive from the subcontinent and other desi-NRI-diasporic outposts each month: 4 out of 10 start-ups in California's Silicon Valley are initiated by NRIs, and some have travelled out in pursuit of larger dreams or felt calling from successful positions in regions as far away and apart as South and East Africa, Fiji and Trinidad, Australia and UK, Singapore and northern Europe (their home in some instances for over 2-3 generations). The US has 1\% Indian population (1/3 are under 18 years of age), with some 100,000 students added each year who come to study in colleges and universities, in IT-work-experience platforms, and so on. As is already the case, a sizeable number will climb up the professional ladder to become CEOs, or behind the scenes advisors and developers of major innovations in the electronic, computerization, financial, investment and similar corporate cultures. 
We wonder whether these doubly-deterritorialized transnationals find themselves crossing other kinds of borders as well, in particular caste, and religious and spiritual orthodoxy; some remain liminally in the borderzone.

Thus, for example, members of the large Fiji-Indian religious community that I have observed across California have a rather different orientation to their subcontinental counterparts. It is evident that if one's ancestors from India left some 100 years ago, then they would have been totally immune to the snares of secularism, the secular worldview, the modern pageant for progress, industry, high-level achievements, with its focus on higherlevel education, and so on. Their practices tend to be more informed by orthodoxy as well, though with certain practices constructed from memory rather than actual priestly learning or transmission (as they were non-Brahmin Chota-nagar villagers who had no links with the urban sampradays etc). There is a certain minimalism in their approach to reconfiguration of their identity in the new horizon. I will say more shortly. They do not readily participate in the larger Hindu Fremont and Sunnyvale temples or the Jain Center of Northern California in Milipitas, but instead erect their own mandirs (temples) and mandalis (gatherings) - and prefer to resurrect their own Sathya Sai Baba bhajana (singing) groups, or kirtan (recitation) groups around any major Guru who has had a major impact on them.

Likewise with the Sikh group, although there are fewer linguistic-regional-caste differentiations that set them apart from other Sikh groups, especially those whose recent history (hence unshared) has not been in the subcontinent but elsewhere (again subSaharan Africa, the Middle East, Malaysia, Fiji, Mauritius). Cross-marriage between recent and temporally distant Indian diaspora groups is a somewhat rare phenomenon; indeed, Australian/Canada/NZ/UK-born young Indians who are identifiably closely linked with their clan, or even schooling systems in modern, post-colony India (e.g., the Doon School in Dehradun, or the IITs), have much better chance of 'scoring' a partner in the US (or Canada), and this is increasingly on the rise, as a sense of the shared or common cosmopolitan platform; early it was the 'British Empire', or 'European', now it is one of the pro-choice modernities, or modernity-at-large; a short while back the binding threads of common identity was McDonald's and Coca-Cola, KFC, $60 \mathrm{~min}$, Noel Coward; now it is iMac, Google, Skype, Bollywood, Glocal ethnoscapes, VHS’s Ram/Rajya, Sri Venkateswara, frequent flyer, Garba-Diwali, Guru-Nanak's Birthday, even resurgent Khalistan. I have even heard it said, 'True Indians are Pardesi Indians not the Call Center Indians [who are at best Resident Non-Indians, RNI]! In other words, the appropriation of cultures on the borderzones of hybridity (between tradition and modernity), cosmopolitanism, ascension (the kinship line is not necessarily with ancestors, that is a kind of descent, but rather with peer-groups, and those close and near, even if only at the other end of the ubiquitous cell-phone and Skype connect: Amrika-Hindi bhai-bhai). The BollywoodDisney mega-celluloid industry knows this well and has been out exploiting the imaginary; so Shah Rukh Khan, Salman Khan, Aishwarya Rai, Kareena Kapoor are seen increasingly on shooting sets in New York, San Francisco, Sydney, and the pastures outside Auckland/ NZ. But what also helps is the inclusive and tolerable qualities, as well as hospitality associated with Sikh gurdwaras and Hindu temple and cultural centers. One is surprised how open and embracing the sites of worship are in the diaspora: caste barriers that exist, say, in Viśvanāth temple (where even foreign converts to Hinduism are in principle not permitted), are overridden; there is food in way of gracious prasāds (blessed offerings) and canteen offerings, free langar for anyone who walks into a Sikh gurdwara, crowned with 
larger feasts during auspicious days and festivities. But there are community-help groups, giving advice on rituals that may be performed at home, assistance with preparing final rites for funerals of deceased loved ones, advice on medical care to insurance to Indian grocery outlets in the vicinity (all very welcome to new immigrants, from wherever). Surprisingly, there is a sudden link established or re-established with familiar images of the 'homeland': people, noise, chanting, kirtan, music, bells, incense, camphor, messy sanctums, rasoi-ghar, prasäd-taking, chai, toilet smells, and so on. The NRI as well as the dvidesi is made to feel they've come home. The hard memories of crossing many a border and frontier are left behind in this melting aesthetic and exotically transcendental plane of the Indian Dasein (opening to ways of other being).

\section{Part II}

In the second half of the paper, I wish to engage with Arjun Appadurai's thesis of the tension and transition from the global to the local (glocal) and critique this from the viewpoint of the Austral-Asian experience, while also lauding its applicability in areas as such the Kannagadi-Hydrabadi I.T.-itinerant professionals transiting between Australia and Silicon Valley, and Tamil Hindus moving between ravaged Jaffna, Malaya-Indonesia, and sent adrift on the Pacific waters toward Canada. Supposed Sikh refugees at one time were not far off this subterranean 'pausengi' route. The post-diasporic borderless ethnoscape is examined for its ramifications in the context of the 'in-betwixt' South Asians.

Let me begin this analysis with a short rewind on how Indian émigrés in Australia were able to move from a quasi-indentured status in the late nineteenth century to a greater cosmopolitanism today.

In the late 1890s to 1920s, Indian immigration was a mixture of banished "coolie" recruits, domestic servants, farm-hands and plantation laborers, to camel-drivers and hawkers, comprised mostly of Hindus and Sikhs. Estranged from their families, a good few eventually returned to their homeland. The ethnic-religious identity came to prevail among the few Indians who remained in Australia. Thus, a Hindu-merchant by the name of Pamamull, who came from the Sind region as an opal polisher, gradually built a family opal and jewelry trade that has prosperously continued with his third and fourth generation descendants, who too remain devout Hindus, contributing generously to Hindu-Indian causes. The 20th-century Hindu migration elicits radically different perceptions and response to the challenges that previously faced the 19th-century predecessors. Both internal and external factors have contributed to the change and continuity, paving a way for a distinctive religio-ethnic identity to emerge. The closing decades of the 20th-century, continuing into the 21st-century, have witnessed a more globalized and globalizing pattern in the Hindu and Sikh diasporic experience. Here the local and global seem to be in tension, although some theorists are sanguine about the symbiosis of the two spatial directions, or in their dialectic of disjunctures, ruptures and emergence of new localities, hybrid and hyphenated identities and post-nation, excolony communities. While there is greater freedom of movement and mobility, and ease of transnational or transcontinental communication or connectivity, there are threats to the stability of the migrant communities' long-term presence and identity. Any number of globalizing forces vie for control and a stake in their high-profile achievements, from TNCs eager to pouch the high achievers to extreme religious forces, Hindu, Tamil (and Sikh) conglomerates operating in the diaspora eager to enlist, fleece or embroil their own 
ilk in long-distance (remote-controlled) struggles and fights in or for the homeland. But this much is politics, whether nationalist or of other kinds. Transnationalism is connected more with multiple modernities than with globalization. Under 'modernities' one should include components such as reformed, re-vivified and re-configured traditions, religious and cultural, which might even be in mutual competition (as Islam is said to be with the West, but with a different globalizing intentionality), or which are resistant to certain orders of globalization, particularly economic and capital-determined globality, even though they may instrumentally utilize some of the products of globalization themselves. Fluidity is not the same as porousness; periphery is not necessarily being noncentered; going 'local' is not to become apolitical; integration with one-hand only does not entail hyphenated de-territorialization. Only a simulacrum of identity would remain as a residue if total dissimulation were to go through.

Changes in immigration laws and to an extent increasing labor demand in an industrializing Australia as well as the gradual relaxation of the 'White Australia' mentality, led to gradual increases in immigration, but not until the 1970s. In the 1950s, the migrant community from the subcontinent was just too sparse and scattered for a sense of ethnic-religious identity to blossom. The 1954 census recorded a mere 2,647 Indians in this vast nation. With the end of World War II and the sub-continental Independence, immigration to Australia was open only for those with over 50\% European blood. The late 1950s saw a slight increase in the number of Hindus opting for Australia rather than for England, the United States and Canada. What attracted them most was certainly not the promise of an open environment where religious aspirations could be freely pursued. Rather, for many modern secular Hindus, the sixth continent bore the appeal of a safe refuge from the religious orthodoxies and caste-ridden life back in the subcontinent.

Beginning in the early 1970s, when the 'White Australia' policy was officially dropped, the reception of immigrants changed, although reservations about admitting people with different standards of living, tradition and culture did persist. The overall image of Australia too had changed dramatically from an open rural land to an industrializing, developing nation with professional opportunities. Thus while the 1961 Census recorded a total of 4047 Indians, by 1971 there were 22,930. The number nearly doubled in the 1980 s, reaching 41,730 by 1981 , and some 50,000 in 1986. By 1991 the India-born population in Australia was 61,602, and by 1996 close to 100,000 (1 lakh in Indian terms), which does not include another 10 to 15 thousand Indian students on study visas. The 2006 Census indicated that there were 147,111 India-born people living in Australia. The 2011 Census estimated the numbers to have doubled, the figure rounded to 300,000. The figures of course include people of a wider religious orientation and also those of European descent born in India. ${ }^{1}$ A little under half of the Indian born Australians are Hindus (140,000 according to 2011 Census) and 19\% being Sikhs (70,000), in contrast to Indian-born Christians who constitute 24\%; with much smaller numbers of Indian Muslims, Parsis and Jains. However, in both the larger communities there are increasing numbers of children born in Australia of immigrant parents. Still, in 2015 some 432,700 Australian residents indicated their birthplace to be India - and that is not counting immigrants of Indian descent born in other countries such as Malaysia, Sri Lanka, and Fiji.

The 2011 and 2015 Censuses analyses indicated that Hinduism is the fastest growing religion in Australia, while Punjabi is the fastest growing language. This is significant as this shift towards a preference for South Asian immigrants, especially in the 
professional and semi-skilled sectors, is likely to have an impact on the shaping of the Australian social landscape. Indians are part of that experiment in social and cultural inclusiveness, otherwise known as multiculturalism.

The transnational conduit or routing we refer to however is not confined exclusively to the bilateral yātra (pilgrimage) between India and Australia; it extends to other countries besides India. Professional Hindus have also been drawn from Sri Lanka with increasing numbers arriving from other parts of the world as well, whom diaspora scholars have called 'twice migrants', and even 'thrice' in some cases, where the temporary immigrant has moved from one country to another, usually over a period of two to three generations. An example of the latter would be East African Indians fleeing to Britain during the Idi Amin coup, and later moving to Canada, the U.S., Australia and New Zealand. Thus Hindus living in other former colonies began to migrate to Australia as well: from Malaysia and Singapore, Fiji, Mauritius, British Guyana, the United Kingdom, New Zealand, the southern and eastern African states, and most recently Hong Kong. Two Fijian-led military coups in the late 1980s, exacerbated by a maverick ousting of the Indian-led government, and political upheavals in Sri Lanka and some African states, increased the number of Hindus seeking to leave their adopted homes, and many looked transnationally to Australia. In New Zealand, for instance, Indian Fijians (the majority of whom are Hindus and Sikhs) constitute the largest single group of ethnic South Asians in that (former) dominion, and exploiting the trans-Tasman arrangement, they periodically visit and at times simply relocate to Australia as bona-fide Australian residents (without having to suffer the long delays in processing visa applications to Australia as experienced by their sub-continental Indian and African counterparts). In 2006, there were some 48,000 people living in Australia who were born in Fiji, most of whom had Indian ancestry.

The educational profile of Hindu and Sikh immigrants is considerably and visibly higher than their Australian counterparts. More than 50\% of all Hindus 15 years and older have university qualifications, including $20 \%$ who have post-graduate degrees. Forty-three per cent of all Sikhs in Australia also have university qualifications. Indian-born immigrants have amongst the highest levels of post-secondary education of all immigrant groups. Hindus and Sikhs at one time did badly in skilled vocational qualifications, largely because of their concentration in academic and professional sectors, but all that has changed in recent years with the labor demands in Australia and the lucrative billion-dollar education and trade-training industry. They exhibit high levels of motivation, much due to the postcolonial legacy to "succeed where the master once had ruled", backed by a heritage of traditional learning. The second or third generation Hindus and Sikhs go on to universities, but do not necessarily or in large proportions opt to become doctors, psychiatrists, surgeons, academics, and engineers with the same earnestness as their parents did. Perhaps this is a sign of the post-postcolonial reversal.

Even if some of these new arrivals have skills and training, such as higher degrees in a number of cases, their qualifications are often not recognized in Australia or they may fail to obtain gainful employment in their specific fields. Thus a prominent taxi rank in a suburb of Sydney is known as the "PhD Taxi Rank" (Voigt-Graf 2000). This is so because many of these cab-drivers are community-sponsored academics from an agricultural university in the Punjab on extended leave, who were at one time in great demand in the Australian labor force, but whose qualifications have not earned them equivalent jobs in Australia, and they are waiting to become full Australian residents. 
The subcontinental Hindus, or India-direct migrants, arrived with their cultural, linguistic and religious links with India or Sri Lanka still intact.

These disparate Hindus and Sikhs, like earlier South Asian immigrants, have utilized the educational system for training in skills and achieving social and economic mobility. Many came with money, too, and quickly found themselves in well-salaried positions, choosing to live in select manicured suburbs or housing colonies, though some have struggled to find employment consonant with their qualifications as has happened in other parts of the world (Lessinger 1999). The contribution of Hindus from these regions toward forging a distinctive religious identity in Australia cannot be overlooked. We observe a special kind of inward-looking transnationalism at work in this particular 'twice-thrice' migrant group.

\section{Part III}

\section{Spiritual edifices and religious politics}

In a short span of time, both Hindus and Sikhs have successfully organized themselves, and by drawing on their own professional skills, bureaucratic contacts, and business dealings, they have been able to move towards building spectacular temples to their gods or gurus in various parts of Australia. But again, the emulation is transnational in two directions: toward the U.S. for the initial inspiration and model, and toward India for the resources, template, shilpi (masonry) skills, shipment of the stone-cast gods and the ritual process of installation and sanctification of the divine spaces within the walls of the mandir or gurdwara. It is significant to note that after a period of gestation, the amorphous collective perceives the need for a firm Hindu and Sikh cultural base and temples. Imagining the temple presents a pre-text for the coming together of Hindus and Sikhs in the diaspora. As a signifier for prescribed ritual and interiorized practices the temple enables greater confidence in one's practices. As a permanent presence, the temple and gurdwara make the Hindu and Sikh identity publicly visible. It also provides a matrix for ironing out differences and tensions among the different sectarian and regional groups, or alternatively to bolster political interests of their respective homebased movements. Internal divisions however remain, and fractured groups shift to other sites, adding yet another temple as indeed the gods were added since ancient times to the alleged 33-crore strong pantheon.

I would now like to move to look at some contemporary political engagements among Hindus and Sikhs.

\section{New Found Hinduism}

To recap a little, much of the 20th-century Hindu migration elicits radically different perceptions and responses to the challenges that previously faced the migrants. As noted earlier there is considerable difference in the experiences of the migrants coming in the 19th-century with those arriving in the 20th-century. Certain internal and extraneous factors have contributed to the change and continuity, paving a way for a distinctive religio-ethnic identity to emerge. The diversity of regional, linguistic, and historical backgrounds of Hindus, of course, adds to the complexity of the baggage each group carries with it to a distant shore. The migrants from India and of South Asian descent, or ascent, who would otherwise call themselves Vaiṣnavas, Saaivas, Śaktas, 
Lingāyats, Bhāktas, or Vedāntins, readily identify themselves as "Hindus" (Thanks to the British colonialists who transformed the Persian appellation for people beyond the Sindhu river who may have been known as 'Sindhus'). These "Hindu" migrants in recent years have borne the burden of preserving their respective traditions. They have participated on platforms of multiculturalism and inter-faith meetings, but they are usually unaware of the subtle game of 'authentication by ethnicity' which whitewashes or marginalizes their real political status and equal treatment as citizens of a civil society. One also feels that Australia cannot claim to be the ideal civil society until it is able to deal with the rights and reconciliation issues in respect of the native Aborigines, who have hardly been players in or beneficiaries of the multicultural paradigm.

In any event, unlike western religions, Hinduism's absences are said to preclude fixed doctrines, tight-knit structures, hierarchical governance, and rigid organizational bases with ecclesiastical control. However, Hindus' presence in a foreign land has led to the development of loosely bound societies and organizations which can serve them in a predominantly Christian environment.

There are certain sentiments that can be more readily exploited. For instance, some members of the Hindu community are anxious that the larger temple complexes have become routinely ritualistic and impersonal, neglectful of diasporic needs, in particular education in the vernaculars and transmission of values, Hindu mores and customs to the younger generation. One must add that this is not true of all local Hindu temples. Within the diasporic communities, there is a variety of religious beliefs and political ideas which compete for the attention of the migrants. Some right wing organizations such as the VHP (Vishwa Hindu Parishad, lit: Universal Hindu Organization) and RSS (Rastriya Svayamsevak Sangha, lit: National Volunteer Group), have established themselves in the diasporic spaces, but had succeeded in having a significant influence on the larger Hindu community. It is also heartening to know that the organizers of such bodies here are wary of bringing extremist views to this tolerant land which they have adopted. This transformation is particularly visible in the teachings of the VHS or the Vishwa Hindu Sangha, (lit: Universal Hindu Group). Also calling itself Satsang Parivar' (lit: company of the truth group), with its headquarters in Melbourne, the group is suspected of having links with the Sangh Parivar and the RSS in India, and indeed the Hindutva movement in the diaspora. However, the sway towards the Hindu Right is highly unlikely to bring Hinduism into a confrontational stance with the larger host society or its more liberal platforms. With the recent visit of Prime Minister Narendra Modi to Australia, the patriotic and fervently-nationalist leaning groups within the Hindu community has experienced something of a boost and a certain recognition for their zealous efforts in advancing the rights of Hindus against perceived encroachments by the state and the supposed preferential favoritism meted out towards the Muslim and other minority communities.

There are, to be sure, muted forms of Hindu globalization that are not connected with the Hindutva brigade at all (even though there may be tinges of extreme orthodoxy or conservatism, even controversy, of other sorts embedded in the propagation machinery). We all know of the TM (Transcendental Meditation) ${ }^{\mathrm{ma}}$ movement that globalized itself rather successfully. The movement - as distinct from its founder-guru, Maharishi Maheshyogi, and despite his attempts to write a bhäsya (commentary) on the 1st six chapters of the Bhagavadgītā, which his disciples mispronounce as 'Bhagāwat-Guiter' 
- does not see itself as nor claim to be a Hindu qua Brahmāṇic-Purānic sect, however; so we shall to another example. Take the ISKCON (International Society for Krishna Consciousness) that started with the humble meandering of Srilaprabhupāda Bhaktivedānta Swami fresh off the boat from India in Tompkins Square Park in the then-dangerous East Village of New York, circa 1964. In a short time following the visit of Allen Ginsberg to the park and other intellectual curios such as Gary Snyder around the Krishna en-chanting Guru, the movement took off, first in San Francisco's Haight-Asbury and in a short time spread like wild yājñik fire across the U.S., Latin America, through to the UK, Europe, Africa and Oceania-Pacific. There is a Hare Krishna community and/or temple in every corner of the world. Welcome to the age of Spiritual Globalization, the glocal spiritoscape. Bhaktivedanta was arguably the first architect in the footsteps of Swami Vivekananda (also a Bengali, but of another Vedānta tradition, after his famous speech at the World Parliament of Religion in 1893) to realize the potential in transnationalizing an otherwise local, provincial, sect that hadn't seen past the streets of Puri (or Calcutta) and turn this into a global cult, with a massive publishing outfit, financial and benevolent social-service understructure. Here is Krishna without borders: although Krishna (of the Mahäbhärata) had travelled across South-east Asia all the way to Bali previously, this new emblem and icon successfully incorporated theologies of the Bhägvatam, bhakti-rasa, and vegetarianism from the Sa kïrtam heritage and hermitages of Gaudịya Vaiṣnavism.

Not dissimilar, although not of the same extent, have been the movements of Siddha-Yoga founded by Swami Muktananda, and the wide reach across the globe of Sathya Sai Baba (especially in the diaspora among the well-heeled NRIs), and surpassing both has been the grand forays of ever-thoughtlessly smiling Sri Sri Sri Ravi Shankar of the Art of Living Foundation based on the outskirts of Bengaluru. India will continue to spread its spiritual commodity transnationally even after it is fully industrialized, achieves global economic status on a part with China, and becomes the second fully non-Western country to be fully and irreversibly developed, thanks to the dreams of Narendra Modi and before him of the prophet of Indian liberalization, the previous Prime Minister (while he has the Central Finance Minister in the Congress Government), Manmohan Singh.

\section{9/11 and After}

In the aftermath of 9/11, the Hindu immigrant community, feeling threatened, began to identify strongly with the ideological values of the settler community. They, along with Christians and Buddhists and others, felt uncomfortable and destabilized in the presence of Muslims: not just Muslims making their passage to Australia but also Islam as an international presence in many parts of the world. Regardless of what particular ethnic origin or regional location Muslims might belong to or come from, modern Hindus and Sikhs have an unsettled memory of the centuries of apparent tension and occasional bloodshed between their own kind and Muslims in the subcontinent. During the British Rāj and the nationalist freedom struggle this communal divide led to the partitioning of India and the preservation of distinctive but gender-discriminatory personal law system. Thankfully, such feelings of unease and tension are not likely to be present among members of the younger second generation. 
The events of 9/11, it seems, have accentuated this suspicion in the eyes of many Hindus and Sikhs, both residing in India and in the larger diaspora; indeed, the Hindu Right led by the BJP capitalized on the convergence of the threat of Islamism to external security and the internal threat to the purity of India (Appadurai 2006: 105-110). Thus, religious and cultural imaginaries when they begin their work at collective conscious and unconscious levels become rather complex processes. The Muslims setting fire in February 2002 near Godhra to the train in which Hindus were returning from their pilgrimage to the reclaimed site of Ramjanmabhoomi in Ayodhya (where once stood the Muslim mosque built by Babar claimed by the Hindus to be standing over the birthplace of Rama), brought home this sad truth.

\section{Part IV}

\section{Globalized Hindus and Sikhs}

Now let us move to the last phase of transnationalism that directly involves globalization and only a trace of localization, unlike the previous phases. Globalization has many faces (even inhuman ones), but the part of the process that is relevant to this phase experimentally concerns the even more rapid mobility of personal and social space made possible by the new technologies of space travel, time traversing, longdistance communications, mass-media, and the deregulation of market that leads to the expansion of Transnational Corporations (TNCs), and interconnected 'flows of capital, information and people' (Tambiah 2000).

In the transborder migratory process, or transnationalization, religion too can be desacralized or secularized and stripped of its cultural specificity or local signification and application, even as it is universalized in the name of God. A different kind of operation of labor flow emerges as well, as transnational forces locate and shift the sites of their technological and capital intensive activities. Today it is Hong Kong, tomorrow it could be Sydney, and another day Chattanooga, Atlanta, Toronto, or another globacity site (Globacity is a neologism for highly globalized cities - think of Bangalore with its Call Centres and outsourcing supply services as well as high-end cosmopolitan enclaves, namely names such as Hollywood Town). Arguably, the U.S. appears to be at the helm of this 'vertebrate' ("have-all") system, driving as it does the unfettered forces of high-velocity capitalism, media control, open market economy, trade monopoly, long-distant credit, and multilateral sanctions, leaving 'cellular' identities (the "have nots") feeling fractured, economically disenfranchised, nationally disintegrated, and facing racial extinction, or 'ethnic cleansing' (Appadurai 2006: 22-25; Harvey 1973, 2005).

The most recent group to have become transnational migrants under this globacity trend have been the computer professional wizards from Karnataka. As we know, Bangalore took the lead in transforming itself into a major info-tech city and teaming up with TNCs, software and IT industries in Silicon Valley and other parts of North America (gradually saturating some sectors of this industry in the global arena), and increasingly adding 'Call Center' to the industrial out-sourcing (which may be based anywhere, in any of the third world countries that provides cheap labor by Western standards at least). Software and IT specialists from this region (and lately from Hyderabad, Maharashtra and Gujarat) have been in much demand outside of India. Collectively they own and operate almost the second largest conglomerate (in terms 
of dollar and stock-market value) of IT industries in the United States, and they boast the highest number of 'start-ups'. Australia too was not to be left behind in this global race, and since the late 1980s has permitted a slow but steady stream of IT graduates and professionals to service its own needs, although Indian companies have not been attracted to establish their 'start-ups' and sister operations here (unless they come via the U.S.), other than Call Centers and certain out-sourcing satellite outposts. All the major cities in Australia have up to or over 2,000 Kannadigas gainfully employed in this sector of the industry-which still only equals the number of professionals arriving in the U.S. in any single year! (Voigt-Graf 2000). This is a close-knit cohesive group, and they frequent the Hindu temples in larger numbers than do their north Indian counterparts (with comparable educational and urban background). This shows that social networks are important for maintaining a sense of belonging and identity in the local context as well. Certainly globalization has led to the diversification of migration pattern, but diversification without the mark of difference.

However, unlike the earlier Indian migrants and in stark contrast to the Indian Fijians, the Kannadigas (there are many Marathis in this boat as well) are not the typical 'glocal' residents, for they maintain rather strong links with their home city and parent companies they originally worked for (or remain professionally connected to as part of the transnational network, for even transnationals have a quaint communitarian ethic); and they visit or travel to India more frequently than other Indian settlers do, reinforcing the close links and obligations across the Indian Ocean (Voigt-Graf 2000). Some work hard and save up earnestly so that they can return and live more comfortably in their favorite home city. In addition, they have close connections with the professional diaspora in the United States, where most of their contemporaries or cyber-cousins have relocated, and where they themselves would prefer to be, given that the vocational returns and earning capacities are deemed to be much higher than in Australia, the lower cost of living and a slower pace of life in Australia notwithstanding. Some succeed in moving across after gaining added credentials in a 'Western' setting. Work assignments may take them for short periods to adjacent Asian countries as well, or to the rapidly developing Four Dragons. Like the icons and avatärs of the Hindu pantheon, these are our transnational cyber settlers-in-transit, equipped with tri-band cellular phones and internet-on-the-run, subjecting themselves to more frequent relocation than was the case even with the twice migrated groups. Theirs is not an experience of diasporic dislocation as these are already well-trained global or multitransnational citizens, the veritable products and harbingers of ISD-globacity, who had already achieved the identity status of being resident non-Indian (RNI) while finishing college or landing their first apprentice job in the Indian urban centers.

\section{Part V}

'The global production of locality' and the promises of disjunctured globalization: small numbers at large

What is the identity of those we described under Phase III? Arjun Appadurai argues that the primary identity is diasporic since the immigrants in question wanted to leave India anyway and merge their identity not as a 'resident alien' but as an hyphenated, transnational/postnational American (he is writing in America on the Indian American), who only catches glimpses of her/his life in the dissimulating mirror held up by 
the rustic tribes that flood his neighborhood or work-place and claim him as their very own. This scenario creates an ambivalence in the diasporic citizen of the new world. But Indians are a heterogeneous people, and as we have been at pains to show, their own pattern of migration and settlement, location, dislocation and relocation has been varied - hence the disporia - more so in the Australian context than in the North American context. Appadurai's revised thesis captures the heterogeneity, dislocation and variation in the experience in question. He thus observes:

In the United States and in the ten or so most wealthy countries of the world, globalization is certainly a positive buzzword for corporate elites and their political allies. But for migrants, people of color, and other marginals (the so-called South in the North, it is a source of worry about inclusion, jobs, and deeper marginalization. (2006: 35)

On the positive side of globalization - which is not measured by the welcome gestures of the 'vertebrate' nation-states - Appadurai's thesis argues for radical disjunctions in the process of globalization, especially against the views of Wallerstein, Robertson, Rosenau, who align contemporary globalization to the spread of the nation form, dictated by the concurrent spread of colonialism and print capitalism - i.e., the stress remains on nationalism and nation-state, de-emphasizing global journeys of capitalist modes of thought and organization. As against this, Appadurai wants to tie in the global with the local and postnational, deterritorialization, the unboundedness or porousness of territory and cultural productions following decolonization, and particularly in the emergence of immigrant, diasporic, and transnational movement or experience (1996:188). All of this makes for an argument for the production of locality, as he construes this trope. Appadurai avers that globalization is 'itself a deeply historical, uneven, and even localizing process' (1996: 17). He welcomes heterogeneity that does not any longer demand strict adherence to the liberal, social contract of the modern West; rather there is greater role to be played by culturism (modern ethnic movements) and imagination even in a world of schizoid rootlessness and alienation. For him, post-industrial cultural productions have entered a post-nostalgic phase. Furthermore, it is terms like the 'image, the imagined, the imaginary' that 'direct us to something critical and new in global cultural processes: the imagination as a social practice. (1996: 31) Appadurai captures his thesis most succinctly in the following passage:

The many displaced, deterritorialized, and transient populations that constitute today's ethnoscapes are engaged in the construction of locality, as a structure of feeling, often in the face of the erosion, dispersal, and implosion of neighbourhoods as coherent social formations. This disjuncture between neighbourhoods as social formations and locality as a property of social life is not without historical precedent, given that long-distance trace, forced migrations, and political exits are very widespread in the historical record. What is new is the disjuncture between these processes and the mass-mediated discourses and practices (including those of economic liberalization, multiculturalism, human rights, and refugee claims) that now surround the nation-state. (1996: 199).

Modernization has made all this possible as an affect and after-effect (hence 'modernity at large'). Its own creation of diverse spaces and mechanisms (for communication, 
relocations, mobilization of people, distinctions all intended for homogenization and disciplinary-control), also unwittingly ensues in informal techniques for subversion, evasion, and resistance, sometimes scatological, sometimes ironic, sometimes covert, sometimes spontaneous etc. (1996: 191).

If Appadurai is right, and the race is on to join the modern in 'self-exile', one still needs to ask how systematically (and not just systemically) organized, consciously planned and productive is the race in terms of culturalist and re-localization trace movements? How self-conscious are the 'self-exiled' of their historical identity, culture, and genealogies or heritage that are not already tied to commercial consumption and monetary mobilization? And whether the suffering, identity crisis, gender-based abuse, discriminatory experience of each and every member are taken seriously, dealt with through cultural and political institutions constructed by the groups themselves, remain to be seen.

Granted, the globalization of culture involves the use of a variety of instruments of homogenization - armament, advertising campaigns, language hegemonies, and clothing styles. But these are also weapons of cannibalization and false reproductions. Nevertheless, Appadurai has explanatory devices to circumvent such threatening counter-examples and has confidence in the dynamics of benign global cultural flows even within the optic fibrous corridors of the narrow specialization in single-state hitech and financial sectors that may profoundly determine 'the shape that ethnoscapes, ideoscapes, and mediascapes may take' (1996: 47).

\section{Part VI}

\section{Deterritorialization revisited}

We have found some of the salient insights in Appadurai's thesis, particularly after the publication of his Fear of Small Numbers: An Essay on the Geography of Anger (2006), helpful in our study of Indian communities both in Australia and in South-east U.S. Appadurai concurs that the old order of things and settled ways of life (on the part of the immigrant groups) are increasingly hard to find. He is also right when he observes that 'The United States, always in its self-perception a land of immigrants, finds itself awash with global diasporas, no longer a closed space for the melting pot to work its magic, but yet another diasporic switching point. People come here to seek their fortunes, but they are no longer content to leave their homelands behind... most groups that wish to renegotiate their links to their diasporic identities from their American vantage points are now free to do so... thus... Indian doctors from Michigan set up eye clinic in New Delhi' (1996: 172). Ruefully he notes, 'The formula of hyphenation (... as Asian-Americans, and African-Americans) is reaching the point of saturation, and the right hand-side of the hyphen can barely contain the unruliness of the left-hand side.' (ibid)

\section{From gokulam to glocalum}

Indeed, there is no gainsaying that Hindus and Sikhs in their hyphenated identity (as Indian-American first, and Hindus/Sikhs as their second calling) in the diaspora have learned (with their left-hand) to organize themselves as religious bodies and raise funds (with tax-free breaks for their own kind), erect as many large temples as possible as part of the sacralizing act of "recreating" their erstwhile Indian or imagined religious 
site, culture and ecology, and they dot these shrines across the landscape of the United States and Australia. They have further understood what it is to be 'aggressive and assertive' for their rights and culture (as the transnational Hindu fronts, VHP, BJP, and the platoon of gurus, swamis, cults, etc., with their gaze set on the West, expect of them), but which is their form of 'diasporic nationalism' (underscoring politics of accommodation, integration, assimilation (Tambiah 2000: 175). And, most important of all, success, they have also created voluntary support and start-up networks for their professional aspirants (expatriate and second-generation), with some gestures toward the needy, homeless and the battered in their community. They even send large sums of money and resources back 'home', where they believe they have an interest or a cause to support for - a rhetoric often heard - "we must be giving back something to our mother-country, no?" Even though, at times, the motivation may be simply to provide local jobs, earnings, and dividends for the excess relatives left behind (for space is also limited and exorbitantly costly in the newfound-land). Hindus/Sikhs have not engaged in such transnational-cross border and long-distance exchange, interrelation and politics since probably their cultural conquest of South-east Asia and Malay-Indonesia archipelago back in the sixth to ninth century C.E.. Globalization has indeed made all this possible, perhaps again. The limit of the new modernity is the limit of imagination: new worlds are on the horizon.

However, as Rustom Bharucha has rightly observed, such "[V]irtual struggle...is an illusion, an abdication of direct confrontation", describing it as "the voyeuristic site of a privileged global intelligentsia, who can afford to surf the possibilities of resistance through mediated discourses, transmitted from the trouble spots of third world into the padded cells of first world intellectual production" (Bharucha, Rustom 1998: 178;171; see also 1993) They certainly do not reflect 'the power of mass literacy' in any linguistically or philosophically significant sense, nor do they augur for 'large-scale productions of ethnic affinity', no more there than it happens in the land of hyphenates or disunited states of 'Amrika', or for that matter in the questionable federalism of Australia (or the among the increasingly cosmopolitanized resident non-Indians in the urban locals of the subcontinent).

So while the productions of localities are happening all around us, these are not matched in proportion by radical disjuncture between territory, subjectivity, politics, and collective social movement, or for that matter by the steady erosion, principally due to the force and form of electronic mediation, of the relationship between spatial and virtual neighborhoods, and much less by the slow demise of the nation-state breaking up into neighborhoods of self-defined allegiances and affiliations. As David Ludden argues in the context of modern global development regime that controls the so-called free-market economy, '[imperial] empires form spatially expanding and contracting hence essentially mobile -systems of territorial order' (Ludden, David 2006: 28). In other words, where historically-mapped boundaries fracture, as nations disintegrate or are pushed to disintegration (through engineered famines, war, regime changes, and so on), the imperial forms of power spread their fangs and take control over the emptied spaces, and fill this up with their own national modernity dressed as a universal, saving 'gift'.

At the same time, and this is a paradox that Appadurai is alluding to, there is the unprecedented implosion of 'other subjectivities, caste mobilizations and new ethnicities' or 'ethnic affinities' - empowered imaginary of the marginalized - there are also 
experiences of extreme oppression and containment of their lot under the mobile national economic policies.

These are the realities, then, that in the virtualization of history, culture, religion and politics are driven to the borderlines of 'otherness' as a consequence of the normative and aesthetic abdication of modernity from these troubled locations; and the ambiguous interplay of the two modernities (eastern-western) here leaves much to be desired, or is submerged to the persistent traces and desires of post-modernity.

Appadurai is aware that the localities are fragile, even transient. In North America it is more evident with the conspicuous absence of large hordes of second-generation Asian Indians in the temples (although they are there for traditional dances and no holds barred celebrations and excesses allowed at festivals such as the holi, but this is part of fun and cultural festivities), that the temple congregation is declining in numbers. It becomes a challenge to continue the robust priestly functions that require highly oral-based recitational training in classical Sanskrit or the southern vernaculars. In Australia the trend is almost reversed. Larger number of devotees and worshippers are attending temple rituals, including second and third generation Hindus. This trend can only continue and increase with a constant flow of diasporic believers and transcontinental seekers (who are not detained elsewhere, in other life-forms, by secularism or other rival faiths). And the inflow could cease as soon as the labor demand is exhausted, or the 'masked' protestors outside the WTO-WEF meetings in Seattle or in Melbourne win their right to organize global labor collectives and check the expansionist strategies of TNCs in complicity with the governments of the day. But that doesn't seem to be likely or anywhere in sight at least in Australia. Even local councils, shires and counties are getting involved in celebration of Ganesh Chaturthi, a major festive day on which the eco-friendly icon of the elephantheaded god is taken in tram from an inner-city area to a lake on the outskirts of the metropolis for ritual immersion; the procession is joined in by Hindus of all persuasions and some locals as well. State Emergency Service volunteers escort the procession through the busy streets to the tram depot from where the idol is taken to the lake. ${ }^{2}$

\section{Part VII}

\section{Religion as cultural resource}

While large numbers of devotees may be attending temple rituals in the diaspora community in Australia, some scholars have argued that the nature of religious faith has changed, partly as a result of the globalization of religion. The prominent scholar of religion, James Beckford 2007, for example, has argued that in the Western world, religion is more readily viewed as a cultural resource rather than as a social institution. His thinking has been enlarged and developed by many other scholars (Beckford 2007; Scheifinger 2010). Part of the reason for this change in the nature of religion is that religious rituals have become dis-embedded from their original localities and contexts. In the Western world, this has often been accompanied by a decline in the confidence that people have in religious institutions. It also reflects the fact that much of life is now lived in the Western world without reference to religious symbols or actions. Religious symbols and actions are, for most Westerners, additional sources of meaning or additional community activities, in which people engage as or when they wish rather than being an integral part of their whole way of life. 
There has been some debate among scholars as to whether or to what extent Indian religions in diaspora communities in the Western world has taken on such forms. It has been noted that Hinduism and Sikhism do not have a unified institutional base which can be rejected in the way many Western Christians have rejected their institutions. It has also been argued that Hinduism has never made the distinction between the religious and secular domains of life that have dominated Western thinking about religion. To that extent, Hinduism cannot be clearly separated from other spheres of life as can some other religions (Scheifinger 2010: 329-30). The same would be said of the Sikhs as well.

On the other hand, for many diaspora Hindus, Hinduism is a series of symbols, rituals, even festivities, in which they participate as they wish. Hindu rituals are not omnipresent in diaspora communities such as Australia in ways which dominate every aspect of life. Hindus would often attend temple rituals as they personally feel is appropriate or helpful. They engage in a puja (worship ceremony) at home to the extent they wish to do that. They may or may not choose to decorate their homes with pictures of Hindu images and symbols.

The processes of globalization have not only shaped the identity of the immigrants who have come to Australia, but they have also shaped the ways in which those immigrants and their religious heritage has been received.

For many Australians of European background, the arrival of immigrants from Asia has been part of their experience of globalization. The building of Hindu temples and Sikh gurdwaras has brought home the religious plurality of contemporary Australia. In some ways, it has reinforced the sense that has become common among Australians that the choice of religion can be made by an individual. Up to the 1970s, most Australians saw their religion as part of their heritage. Just as they carried with them the fact that they had been born at a particular place and into a particular community, so they had been born into a religious community. Recent studies among young people in Australia have confirmed that most now see themselves as taking responsibility for any religious commitments they might make, much as they see themselves as taking responsibility for other decisions about life-styles. Religion is something they can turn to for help if they feel they need to. They say that, 'whatever is good for you, whatever works is fine, and whatever you believe is up to you' (Hughes 2007:148).

\section{Conclusion}

Some of the issues for an analysis of transnational diaspora that we have examined in the broader context of movements and transformative shifts within the rubric of 'Experimental Dharma' include the following:

1. How is a tradition like Hinduism or Sikhism with its own unique cultural practices, and moral beliefs 'transplanted/translated/ trans-created' in new, transnational, settings? And how does it undergo change or transformation?

2. How, in turn, is the local host country - its geography, cultural landscape, economic character and symbols - transformed by an ethnic-religious group's need for and negotiated acquisition of social, ritual and cultural (perhaps even political) space? 
3. How do each religion's adherents cope with, survive and stake or strengthen, further claims in the imaginary with loosing substantive grounding in the traditional roots?

4. What is the impact of new religions on the new environments in which they are planted? How do people who have very different heritages respond to these beliefs and practices, which may appear very strange to them?

5. What lasting impacts are left by the experimentalism of Dharma or the dharmaderived traditions in the diasporic dislocation, in dealing with the transnational anomie and the general ontological, epistemological and axiological disruptions experienced?

We have shown that Indian immigration was a mixture of 'coolie' recruits, domestic servants, farmhands and plantation laborers, camel drivers and hawkers, who were primarily Hindus and Sikhs. Estranged from their families, a good few eventually returned to their homeland. The ethnic-religious identity also came to prevail among the few remaining Indians. The closing decades of the 20th-century, continuing into the 21st-century, witnessed a more globalized and globalizing pattern in the Hindu and Sikh diasporic experience. Here the local and global seem to be in tension, although some theorists are sanguine about the symbiosis of the two spatial directions, or in their dialectic of disjunctures, ruptures and emergence of new localities, hybrid and hyphenated identities and post-nation, ex-colony communities. This reinforces our analysis in regard to the distinctive identities that become constructed in the sense of general Indian-ness as well as specific ethnic identity. In the context of transnationalism and globalization, religious communities, through their various religious institutions have, more often than not, also entrenched narrower ethnic identities. A good example is the Swaminarayan communities in the United Kingdom and the United States, where they have perpetuated as a result of their institutional approach to Gujarati linguistic or ethnic identity.

Another example is evident in the experience of the Sikh community, which illustrates how religious communities entrench ethnic identities within the context of globalization through their transnational networks, which run along ethnic lines rather than along broader national lines. It is, as many a scholar of diasporas generally, and of the Hindu-Sikh diaspora, in particular, have pointed out, religion has played a key role in creating or challenging modern identities. In doing so, religious communities recreate not only their conventional identity that they bring to the host society, but also experiment in the crafting of new identities through assimilation and adaptations.

The beginnings may be ever so humble, indentured laborers gathering in a humble shed to recite Tulsidas Rämāyana (Rämacaritamānasa) or prepare for the festivity of Ràmalìlā, but over time their grand edifices begin to compete with the Christian cathedrals or Mughal mahals (palaces). As Rajesh Rai and Chitra Sankaran observe:

Beyond the religious myth-symbol complexes that informed the nostalgia for an 'ancestral homeland' among emigrants, historical records show that in many, if not most locations where stable South Asian diasporas developed, the archetypal institutions directly produced through the agency of these emigrants were typically religious. In the case of the 'old' diaspora born out of colonial capital, the initial structures of these places of worship may have been unassuming - a banyan tree housing a Hindu deity, or simple thatched huts with a corrugated iron roof [serving 
as a gurdwara or a mosque], but that not in itself limit their role as important building blocks for organising and mobilising incipient diasporan communities (Rai, Rajesh and Chitra Sankaran 2011: 7).

While there is greater freedom of movement and mobility, and ease of transnational or transcontinental communication or connectivity, there are threats to the stability of the migrant communities' long-term presence and identity. Any number of globalizing forces vie for control and a stake in their high-profile achievements, from TNCs eager to poach the high achievers, to extreme religious forces, Hindu, Tamil or Sikh, operating in the diaspora and eager to enlist their own kind in long-distance struggles in and fights for the homeland. But this much is politics.

At the same time, the nature of identity and the part that religion plays in that identity for the Australian population has changed. Particularly in the major cities, most Australians are well aware that the Australian identity is often one part of a transnational or global identity. There are Chinese-Australians, Indian-Australians, GreekAustralians and Italian-Australians. For others that identity has become primarily a global identity. Here is a sense of being human beings, first, who happen to be born in Australia (Batrouney and Goldlust 2005). Few Australians now see their identity as Australians to be linked to a particular religious heritage. Religion has become a personal choice, part of a biography that the individual creates. As such, there is an openness to, sometimes a fascination with, religions from various cultures around the world.

Here we cannot help but to echo the sentiments of Tambiah who, we believe, puts it in perspective:

... today there are multiple modernities that are evolving, and...such complex processes cannot be grasped by a general theory of modernity at large or encompassed by blanket terms such as hybridisation, eclecticism, creolisation, deterritorialisation, and so on. Such terms tell us something but not enough (Tambiah 2000: 189).

No less so in the broader Australian society. Here, too, the Hindu temple, along with the smoke from the Ārya Samāji fire-oblation and the chants of the Granth-Sahib in the Sikh gurdwara, symbolize the struggles within a multicultural and ethnically pluralizing society. In the background is the long and rich tradition, heritage and culture of the native or Aboriginal people, struggling to survive. Sadly there isn't much interaction of these new religions with Indigenous Aboriginal communities or cultures. This lack does not hold much promise toward a fusion of discordant horizons to produce a 'new tradition' we may call it 'post-secular modernity' - that is critically tolerant, morally more enlightened, artistic and truly democratic. Such is the hope of some intellectuals and folks of the country. Nevertheless, religious diversity is a reality that Australia can no longer ignore, despite the anxiety to preserve the homogenizing hegemony of AngloCeltic identity against the challenges of transnational pluralism, and especially of globalization or globality that threatens to bring about radical changes in the much shorter span of time than piecemeal social engineering accomplished over a century or two, for better or for worse. But globalization, unlike earlier trans-territorial transactions and transcreations does not augur good news for the expatriate/diaspora/disporia communities, for the universalism and sheer speed of capital or monetary motivated flow and 
changes will surely wash away all local cultural capital and location of dignified social, cultural and religious presence. Religion in self-exile, as with Tibetan Buddhism and its temporal seat, may well be the fate of religions in the globality space and post-colony time - at home in memory only, and still in search of a stable identity elsewhere.

\section{Endnotes}

${ }^{1}$ Extracted from various tables provided by the Australian Bureau of Statistics from the various Censuses right up to 2015 national census. This essay is indebted to material and analyses amassed in a growing body of literature by the author and his Australian collaborators; in main: Bilimoria 2016; Bilimoria 1998; Bilimoria, Bapat \& Hughes 2015; Bilimoria and Rayner 2014.

${ }^{2}$ Since 2003, a north-west Council of Melbourne, The City of Darebin, has been actively involved in this celebration of the Ganesh Chaturthi. It is noteworthy that it was one of the Australian councillors made the initial approach to one of us (JBB) for starting this celebration and got the local tram company and certain local corporations are involved in it as well. The money placed in front of the god by the devotees is donated to the state electricity board.

\section{Acknowledgement}

The author expresses deep gratitude to Colette Walker and Antoinette DeNapoli for help with editing at various stages of the text's evolution; and also to Oliver Freiberger for helpful suggestions.

Received: 20 February 2017 Accepted: 22 March 2017

Published online: 19 July 2017

\section{References}

Appadurai, Arjun. 1996. Modernity at Large: Cultural Dimensions of Globalization. Minneapolis/London: University of Michigan Press.

Appadurai, Arjun. 2006. Fear of Small Numbers: An Essay on the Geography of Anger. Durham/Raleigh and London: Duke University Press.

Beckford, James. 2007. The Sage Handbook of the Sociology of Religion. UK: Sage Publications.

Batrouney, T., and J. Goldlust. 2005. Unravelling Identity: Immigrants, Identity and Citizenship in Australia. Altona: Common Ground Publishing.

Bharucha, Rustom. 1993. Theatre of the World: Performance and the Politics of Culture. London: Routledge.

Bharucha, Rustom. 1998. "The Shifting Sites of Secularism-Cultural Politics and Activism in India Today." Economic and Political Weekly vol 33 no 4 (January): 167-81.

Bilimoria, P and Rayner A, (eds). 2014. Globalization: Transnational, Gender and Ecological Engagements (edited with Amy Rayner), New Delhi: Serial Publications.

Bilimoria, Purushottama; Bapat, Jayant Bhalchandra, and Hughes, Philip (eds). 2015. The Indian Diaspora Hindus and Sikhs in Australia. New Delhi: DKPrintworld (1st edition); (2017) 2nd edition, Melbourne: Numen Press.

Bilimoria, Purushottama. 2016. 'Totaram Sandhya and his experience of Racism in White Australia c.1920s', Nidān: International Journal of Indian Studies (KwaZulu, Natal, S.A.), Volume 1, No. 1, July; pp. 8-23. also in Fijian Studies (2016) 14(1), pp. 71-88.

Bilimoria, Purushottama. 1998. 'Speaking of the Hindu Diaspora in Australia' Hindu-Christian Studies (Bulletin) Vol 11, June, pp. 11-19.

Cohen, Robin. 1997. Global Diasporas: An Introduction. London: UCL Press.

Harvey, David. 1973. Social Justice and the City. London: Edward Arnold.

Harvey, David. 2005. A Brief History of Neoliberalism. New York: Oxford University Press.

Hinnells, John. 1998. "Comparative Reflections on South Asian Religion in International Migration." In The New Penguin Handbook of Living Religions (2nd edn.), ed. John Hinnells, 199 paperback: 819-48. Oxford/Cambridge, MA: Blackwell Publishers; London.

Hughes, Philip. 2007. Putting Life Together: Findings from Australian Youth Spirituality Research. Melbourne: Christian Research Association.

Lessinger, Johanna. 1999. Class, Race and Success: Indian-Americans Confront the American Dream. In Carla Petievich. New Delhi: Manohar.

Ludden, David. 2006. "History and Inequality." IIAS Newsletter 42 (Autumn): 28-29. Full text at http://www.iias.nl/ wertheim/?q=nodes/5. Accessed 2 Nov 2011.

Mignolo, Walter D. 2009. The Enduring Enchantment (Or the Epistemic Privilege of Modernity and Where To Go from Here). In Postcolonial Philosophy of Religion, ed. P. Bilimoria and A. Irvin, 273-94. Dordrecht/NY: Springer.

Mishra, Sudesh. 2006. Diaspora Criticism. Edinburgh: University of Edinburgh Press.

Rai, Rajesh and Chitra Sankaran. 2011. "Religion and South Asian Diaspora" (Introduction to Special Issue on 'Religion and the South Asian Diaspora'). South Asian Diaspora, vol 3 no 2 (March): 5-13. 
Scheifinger, Heinz. 2010. Om-line Hinduism: World Wide Gods on the Web. Australian Religion Studies Review 23(3):325-45. Tambiah, Stanley, 2000. Transnational Movements, Diaspora, and Multiple Modernities. Daedalus: Journal of American Academy of Arts and Sciences, Winter Issue on Multiple Modernities. 129:163-194.

Vertovec, Steven. 1995. Hindus in Trinidad and Britain: Ethnic Religion, Reification, and the Politics of Public Space. In In Nation and Migration: The Politics of Space in the South Asian Diaspora, ed. Peter van der Veer and Peter van der Veer. Philadelphia: University of Pennsylvania Press.

Voigt-Graf, Carmen. 2000. Indians at Home in Australia: A Highly Diverse Transnational Community. Delhi: Paper Presented at the International Conference on Culture and Economy in the Indian Diaspora.

\section{Submit your manuscript to a SpringerOpen ${ }^{0}$ journal and benefit from:}

- Convenient online submission

- Rigorous peer review

- Immediate publication on acceptance

- Open access: articles freely available online

- High visibility within the field

- Retaining the copyright to your article

Submit your next manuscript at $>$ springeropen.com 